and useful "how to" hints. Jennings" comments create a provocative dialogue with his on-air performances.

8. Interview in Moscow with Sergei Erofeev (1988).

9. M.M. Bakhtin 1981. The Dialogic Imagination. Austin: University of Texas Press. p. 416-419.

10. Gary Saul Morson, ed. 1986. Bakhtin: Essays and Dialogues on his Work. Chicago: University of Chicago Press.

11. I wish to thank Charles Benton for his persistent support of my research and especially for his encouragement of the thinking I have been doing along these lines of creating new forms of television through intercultural production. I am deeply appreciative to the Benton Foundation and the MacArthur Foundation for their support of my research and production. Many thanks especially to Michael Cole without whom none of this could have possibly started or continued and to Tracy B. Strong for continuing help and support.

\begin{abstract}
About the Author
Helene Keyssar is a professor of communications at the University of California, San Diego. Her most recent book is Robert Altman's America (1992, Oxford University Press).
\end{abstract}

\title{
Oyez, Oyez, Oyez: The Trials of Teaching the Supreme Court
}

\author{
Nancy V. Baker, New Mexico State University
}

The law is more than a list of case names and facts, and courts are not neutral mechanisms dispensing "justice" like so many cans of cola. Political scientists who teach public law may feel frustrated that an anachronistic jurisprudence of impartiality continues to dominate much of the teaching about law. These faculty may find that classroom simulations, particularly mock trials, can be used to dramatize the interaction between law and politics in a way that the traditional casebook method does not. The mystique that is carefully maintained by the judiciary and many law schools can be lifted if students themselves assume the roles of particular Supreme Court justices.

One aspect of the old view of the law is the assertion that "the judge begins with some rule or principle of law as his premise, applies this premise to the facts, and thus arrives at his decision," a myth critiqued in the work of Jerome Frank in the 1930s (Frank 1963). Another aspect is the excessive but superficial deference paid to precedent, according to Karl Llewellyn (1951), since explicitly overturning prior rulings "would undermine the dogma of the infallibility of the courts" (Llewellyn 1951, 64). A third aspect is the continuing "myth of merit" outlined by David O'Brien (1990)-the notion that judicial appointments are made on the basis of merit alone.

In general, the legal system con- tinues to portray itself as above politics and personal skirmishes. Recall the judicial dismay at the 1979 publication of Woodward and Armstrong's The Brethren, and the recent release of Peter Irons's May It Please the Court, complete with tapes of oral arguments before the Supreme Court. Critical of both books, the justices have argued that secrecy is essential to maintain the prestige and credibility of the institution, e.g., the illusion that legal decisions are value neutral.

A mock trial can help to dispel these myths. Through the research stage, oral argument and conferences, student justices experience a wide range of social, personal, and political factors that contribute to the outcome of a case. A mock trial has other advantages as well: students must become personally engaged in the learning process, and active learning helps students comprehend and remember substantive material. In addition, students become acquainted during the exercise, leading to increased student participation through the rest of the semester. The format of a mock trial also provides an arena where particular legal issues may be debated, court processes dramatized, and oral skills honed. Finally, a simulation like this breaks the monotony of lecturing for both instructor and class toward the end of the term, when an infusion of enthusiasm and energy is welcome.

Simulations have been variously defined as "operating models of physical or social situations" (Nesbitt 1971,4$)$ and "simplified reality"' (Twelker and Layden 1973, 445). In a sense, they are case studies, "with the participants on the inside, not on the outside" (Jones 1980, 10-11). Classroom simulations in political science are not new, but a review of the literature suggests that they are used more extensively in the areas of public policy and international relations than in public law and the courts. ${ }^{1}$ Faculty who teach undergraduate law courses may be missing a valuable adjunct to the lecture format.

Mock trials combine two types of simulations: interpersonal and large system. An interpersonal simulation creates a scenario in which students act and react as if they were genuine players in the system. The Supreme Court simulation requires this type of role playing among participants who must assume specific personas in the decision-making process. In contrast, a large system simulation creates a more complex context in which students analyze information, make decisions, and evaluate outcomes. The emphasis, instead of being on individual behavior, is on the aggregate (Twelker and Layden 1973, 446-447). Here again the Supreme Court simulation provides opportunities, since the simulation is not truly open ended. The actors operate in a particular institutional setting, constrained by convention, case law, the Constitution, public 
opinion, etc. The justices must operate within the larger political community, and their decision making reflects this.

The following simulation was designed for undergraduate classes in constitutional law, Supreme Court, civil liberties, and judicial process. A scaled-down version may be adapted for introductory classes in American government. This version assumes a class of approximately fifty students, but it may be adjusted in either direction. A minimum of eleven students is needed per case-nine as justices and two as attorneys. By adding two more attorneys, thirteen students may participate on each case. Six class sessions are required for this simulation, and outside meetings to discuss the case are encouraged.

By scheduling the moot court later in the semester, the class already will have covered the fundamental lessons about the Supreme Court, including selection of justices, agenda setting, decision making, interbranch relations, workload, norms, and constitutional theories.

Early in the semester, divide a class of fifty into four Supreme Courts, with each student assigned to be a particular justice or an attorney. The personality of each court will vary according to the ability of the chief justice; as in real life, the task and social leadership roles may devolve onto other actors on the court. Generally, more advanced students are assigned to play the pivotal roles, including the chief justice and the attorneys. Students researching their justices should seek information on background, world view, voting patterns, relations with others on the court, and philosophy.

Six weeks prior to the start of the simulation, the court docket is announced, giving students sufficient time to research their cases. The cases themselves are drawn from existing case law, but with facts altered enough so that students cannot mimic the actual court. Among the cases I have used are Rankin v. McPherson (1987), Cruzan v. Missouri Dept. of Public Health (1990), Board of Trustees of Scarsdale v. McCleary
(1985), and National Treasury Employees Union v. Von Raab (1989). Each is involved with a civil liberties issue; the docket could easily be altered to reflect a different class orientation.

Over four successive class periods, each Supreme Court meets to hear oral arguments; justices may vigorously question the attorneys or sympathetically assist one side. The chief justice monitors the session to ensure that the attorneys do not exceed their allotted time. During the fifth class period, the justices meet in conference to discuss and vote on each case; attorneys are excused from class. At the last

\section{The mystique that is carefully maintained by the judiciary and many law schools can be lifted if students themselves assume the roles of particular Supreme Court justices.}

session, each Court assembles in turn at the front of the room to deliver its ruling; the chief justice presides and, if in the majority, announces the court's decision and reasoning. Concurring and dissenting justices speak as well. Then class members have the opportunity to question the attorneys and the justices.

There is an advantage to having an audience. Not only do justices and attorneys seem to take their roles more seriously, but audience members have an opportunity to get an overview of court dynamics, which may not be clear to them when they are actual participants. Furthermore, audience members may assess how other students have interpreted the views of the various justices on different legal questions. In one of my classes, for example, three Justice Scalias watched in amazement as the fourth Justice Scalia voted with the court's liberal wing in a Fourth Amendment case. During discussions that followed, the "liberalleaning" Scalia explained that his actions were consistent with the ideologically conservative justice. In sum, students are engaged in teaching each other.

Research and writing are important components of the simulation. Justices are required to research and write bench memos for use during oral arguments, including questions that they plan to ask the attorneys. They also must write either a majority, concurring, or dissenting opinion following the conference. Attorneys must submit their legal briefs to the justices two days in advance of oral argument. Attorneys also are required to write an assessment of how each justice is likely to vote on the issue. Copies of all written material are given to the instructor.

The objectives of the Supreme Court simulation are essentially threefold. The first is to build skills. Students must read and comprehend court cases and cull the important points. They must research and write bench memos and briefs. In terms of public speaking, students must be able to ask and answer questions in front of the class, attempt to persuade their colleagues during conference sessions, and then present their formal conclusions.

Another goal is to build a knowledge base. By the time of the simulation, students already have had the core material relating to the Supreme Court. This activity requires students to do in-depth research on a particular justice and legal issue prior to the trial. Furthermore, it requires students to synthesize earlier lessons with their experiential knowledge.

Finally, the simulation can provide insight into the dynamics of the decision-making process on the court, including the various overt and covert factors that may influence the outcome of a case, political, personal, or institutional. Students, in other words, have the veil lifted; the myth of the court as a neutral and apolitical body is destroyed. 


\section{Briefs for Justices}

1. Title of case (centered at top of page, underlined).

2. Your name (the justice you personify).

3. Statement of the facts leading up to the case (as given to the class; some elaboration is permissible if necessary and the other mock trial participants agree).

4. Statement of the issues. What legal questions face the court? Remember that the Court sometimes must decide justiciability first. Phrase the issues as specific questions.

5. Your ruling as a justice on the various questions above (No, Yes). Note if you believe the case should be remanded to the lower courts, affirmed, granted an injunction, or whatever.

6. Your reasoning. Cite precedents, tradition, logic, sociology, constitutional language, original intent, etc., to support your view and to criticize the opposing view. Be consistent with your justice, not only in HOW you vote, but WHY.

7. Assess how your justice's personal views did or did not affect your ruling.

8. Following your conference, write any additional comments you wish to make about the case. Note if your justice was able to sway others and why or why not. Identify who has been assigned the majority opinion, and by whom. If you are a chief justice, tally the votes, including any ones that are dissenting in part/concurring in part.

\section{Briefs for Attorneys}

1. Title of case (centered at top of page, underlined).

2. Your role before the Court.

3. Statement of the facts leading up to the case (as given to the class; some elaboration is permissible if necessary and the other mock trial participants agree).

4. Statement of the issues. What legal questions face the court? Remember that the Court sometimes must decide justiciability first. Phrase the issues as specific questions.

5. How your client would like to see those questions answered.

6. Your full argument on behalf of your client: precedents, logic, tradition, sociology, constitutional language, original intent, etc. Also argue why the opposing side is wrong.

7. In a separate report to the instructor, assess how each justice may vote, given what you know of that justice. Then explain how you have tailored your argument to keep sympathetic justices and to attract those who are undecided.

\section{Notes}

1. See, for example, Charles White, "Bringing Nuclear Escape into the Classroom," Social Education, March 1990, v. 54, n. 3; Linda K. Fuller, "Taking Terrorism into the Classroom," Journal of Popular Culture, Summer 1991, v. 25, n. 1; Eileen Hilke and Ray Skrentny, "A Study and Simulation of International Trade," Social Education, Jan. 1990, v. 54, n. 1; “Curbing CO2 Emissions," The Science Teacher,
Sept. 1990, v. 57, n. 6; and Kathleen K. McQuaid, "Guided Design Simulations in Introductory Level American Politics and State and Local Politics Courses," PS: Political Science \& Politics, Sept. 1992, v. 25, n. 3.

\section{References}

Frank, Jerome. 1963. Law and the Modern Mind. New York: Anchor Books.

Irons, Peter. 1993. May It Please the Court. New York: New Press.

Jones, Ken. 1980. Simulations: A Handbook for Teachers. London: Kogan Page.

Llewellyn, Karl L. 1951. The Bramble Bush. Oceana Press Pubs.

Nesbitt, William A. 1971. Simulation Games for the Social Studies Classroom. Foreign Policy Association.

O'Brien, David M. 1990. Storm Center: The Supreme Court in American Politics. New York: W.W. Norton.

Twelker, Paul, and Kent Layden. 1973. “A Basic Reference Shelf on Simulation and Gaming" in David Zuckerman and Robert Horn, eds. The Guide to Simulations/ Games for Education and Training. Lexington, Mass: Information Services.

Woodward, Bob, and Scott Armstrong. 1979. The Brethren: Inside the Supreme Court. New York: Simon and Schuster.

\section{About the Author \\ Nancy $V$. Baker is an assistant professor of government at New Mexico State Univer- sity, where she teaches in the areas of public law and the presidency. She is the author of Conflicting Loyalties: Law and Politics in the Attorney General's Office (Kansas,} 1992). 